\title{
As facetas de Clio por Oliveira Viana: análise crítica do seu discurso de posse no Instituto Histórico Geográfico Brasileiro (IHGB - 1924)
}

\author{
The facets of Clio by Oliveira Viana: critical analysis \\ of his inaugural speech at the Brazilian Geographic Historical Institute (IHGB - 1924) \\ Las facetas de Clio por Oliveira Viana: análisis crítico de su discurso de inauguración \\ en el Instituto Histórico Geográfico Brasileño (IHGB - 1924)
}

Piero Detoni ${ }^{1}$

\begin{abstract}
Resumo
DETONI, Piero. As facetas de Clio por Oliveira Viana: análise crítica do seu discurso de posse no IHGB (1924). Rev. C\&Trópico, v. 44, n. 2, p. 196-232, 2020.

DOI: https://doi.org/10.33148/cetropicov44n2(2020)art7

O discurso de posse de Oliveira Viana no IHGB serve de pretexto para investigarmos as transformações epistemológicas que afetam o conhecimento histórico nos anos 1920. Viana parece ter uma aguda consciência acerca dos desafios colocados aos espaços de trabalho do historiador. Este estudo evidencia quais as rupturas e quais as continuidades epistemológicas estão presentes neste discurso diante das pressões e das exigências contextuais. Acreditamos que a posição de Oliveira Viana seja demandada por parte significativa dos sócios do IHGB que pretendem superar a prática historiográfica até então operada na instituição. Esta peça discursiva é, além do mais, oportuna por proporcionar um novo olhar sobre as formas como Oliveira Viana, importante intérprete do Brasil, constrói as suas obras na referida ambiência.
\end{abstract}

Palavras-Chave: Epistemologia. História da historiografia brasileira. IHGB. Oliveira Viana.

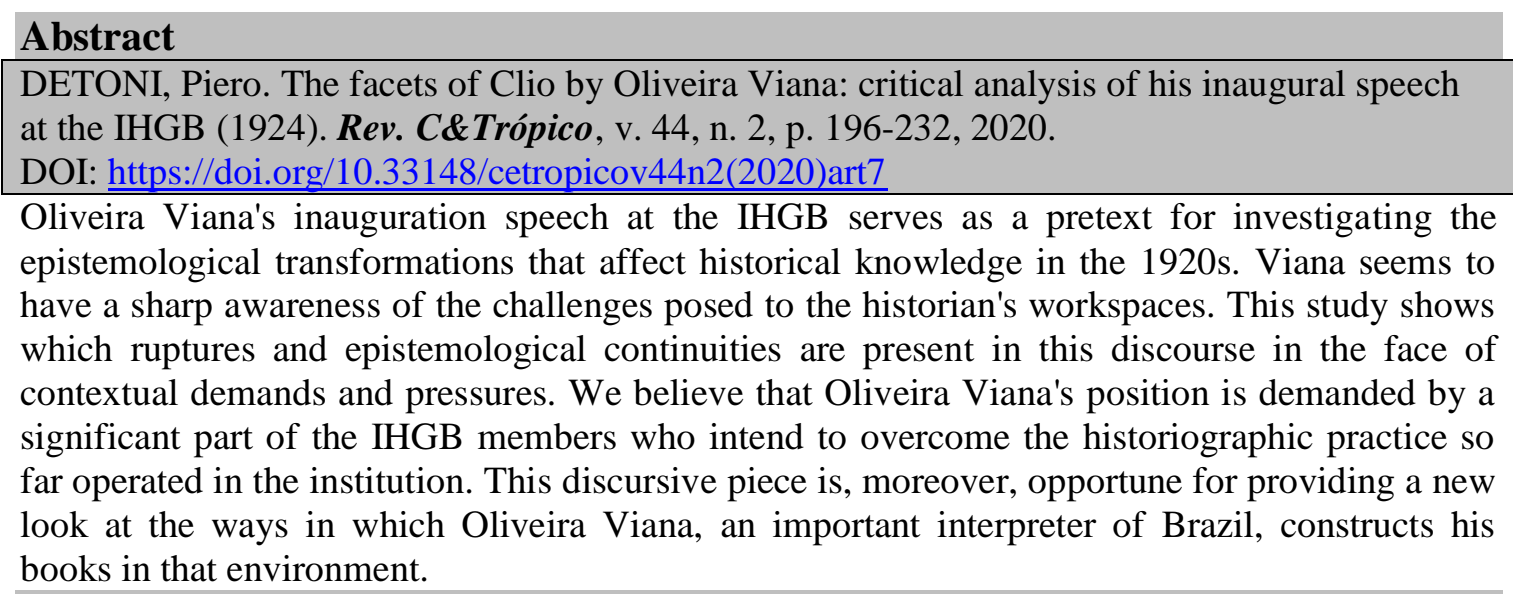

Keywords: Epistemology. History of Brazilian historiography. IHGB. Oliveira Viana.

Resumen
DETONI, Piero. Las facetas de Clio por Oliveira Viana: análises crítico de su discurso de
inauguración en el IHGB (1924). Rev. C\&Trópico, v. 44, n. 2, p. 196-232, 2020.
DOI: https://doi.org/10.33148/cetropicov44n2(2020)art7
El discurso de inauguración de Oliveira Viana en el IHGB sirve de pretexto para investigar las
transformaciones epistemológicas que afectan el conocimiento histórico en la década de 1920.
Viana parece tener una aguda conciencia de los desafíos que se plantean a los espacios de
trabajo del historiador. Este estudio muestra qué rupturas y continuidades epistemológicas están
presentes en este discurso frente a las demandas y presiones contextuales. Creemos que la
posición de Oliveira Viana es demandada por una parte significativa de los miembros del IHGB
que pretenden superar la práctica historiográfica que hasta ahora operaba en la institución. Esta
pieza discursiva es, además, oportuna para dar una nueva mirada a las formas en que Oliveira
Viana, importante intérprete de Brasil, construye sus obras en ese ambiente. Palabras clave: Epistemología. historia de la historiografía brasileña; IHGB; Oliveira Viana

\footnotetext{
${ }^{1}$ Doutorando em História Social na Universidade de São Paulo (USP). Licenciado, bacharel e mestre em História pela Universidade Federal de Ouro Preto (UFOP). ORCID https://orcid.org/0000-0002-51067868. E-mail: pierodetoni@gmail.com
} 


\section{Oliveira Viana entre historiadores}

O discurso de posse de Francisco José de Oliveira Viana no Instituto Histórico e Geográfico Brasileiro (IHGB) pode ser considerado, de alguma maneira, uma espécie de marco em se tratando de epistemologia da história no Brasil. Parece-nos que o famoso autor das Populações meridionais do Brasil (1920), livro que o consagra como um dos mais notáveis intérpretes do Brasil naquela ambiência intelectual dos anos 1920, possui uma consciência consistente acerca do desenvolvimento dos estudos históricos no Brasil, sendo que o seu discurso reúne uma série de prescrições e de elementos que começam a ser percebidos nos espaços de atuação disciplinar próprios dos historiadores nacionais. Eleito sócio efetivo em 18 de julho de 1924, ocupando a cadeira de Aurelino Leal, Viana é recebido no grêmio por Max Fleiuss, Agenor de Roure, Jonatas Serrano, Laudelino Freire, Camelo Lampreia e Raul Tavares. Mas o seu discurso de posse extrapola os salões do IHGB. Ele é publicado, no mesmo ano, na importante Revista do Brasil com um título mais do que sugestivo: $O$ valor pragmático do estudo do passado.

A escolha de Oliveira Viana como sócio não deixa de ser uma estratégia intelectual por parte da instituição, pois ao recrutá-lo o IHGB passa a ser figurado como um espaço de trabalho atualizado nas discussões mais recentes em ciências sociais de modo geral, algo que a sua obra representa na década de 1920. Assim sendo, como quer Michel de Certeau, é "impossível analisar o discurso histórico independentemente da instituição em função do qual ele se organiza silenciosamente" (CERTEAU 2006, p. 71). É através das articulações pontuais entre as prescrições de Viana e as atividades do IHGB que novos métodos emergem, que interesses investigativos são delineados e que fontes e problemas são (re)organizados epistemologicamente. As relações entre o estudioso carioca e a instituição se entrecruzam, além do mais, em um programa epistêmico que elege a "retórica da neutralidade" como atitude intelectual, o que leva ambos a se portarem apartidários e céticos em relação aos movimentos políticos oficiais, mesmo que em um horizonte mais amplo a descrença com a República seja acentuada em Oliveira Viana. Mas isso não significa um niilismo em termos de política e de usos políticos do passado. Viana e o Instituto fomentam o civismo e o patriotismo, mesmo que em Viana haja um registro ético-político no mínimo duvidoso. De qualquer forma, a neutralidade e a objetividade das ciências humanas podem ser conferidas em sua obra de estreia, as Populações meridionais do Brasil (1920), corroborando os ensejos do IHGB: 
para obterem dele uma reconstituição, tanto quanto possível, rigorosa (VIANA, 1920, p. 14).

Enquanto intérprete do Brasil de reconhecido destaque na cena intelectual dos anos 20 o estudioso fluminense, a partir do seu discurso de posse no IHGB, pôde nos oferecer pistas sobre as identidades disciplinares da história e das ciências sociais naquele contexto. Mais: este discurso de posse parece-nos útil por nos informar qual o lugar da história na epistemologia proposta pelo próprio Oliveira Viana, abrindo a possibilidade de novas leituras sobre livros importantes escritos pelo intelectual, entre eles o centenário Populações meridionais do Brasil (1920). Viana é dono de uma vasta obra que transita por diferentes disciplinas: história, sociologia, psicologia, antropologia, ciência política, direito, sem que se chegue a um consenso sobre qual o tipo de abordagem é priorizado. É plausível afirmar, em um primeiro lance de vista, que a sua obra seja interdisciplinar. Mas o seu discurso de posse oferece a possibilidade de conhecermos a orientação implícita percebida entre esses saberes em um registro interdisciplinar, isto é, a síntese histórica. Salientamos que este discurso é revelador tanto dos desejos de pesquisa de Oliveira Viana quanto de parte do IHGB. Ele aparece como um caso que movimenta toda uma estrutura de conhecimento.

Angela de Castro Gomes salienta, em sua leitura sobre o discurso de Oliveira Viana no IHGB, que as aproximações entre o intelectual e a instituição são, certamente, tanto intelectuais quanto políticas, visto que todos conhecem o seu posicionamento crítico quanto aos horizontes da ação política na Primeira República (o seu estatismo), bem como a sua admiração indisfarçada pelo Império (a centralização política), uma disposição que o faz ser recrutado pelas sensibilidades históricas em destaque na instituição (GOMES, 2009, p. 68). Ou seja, as aproximações entre o Instituto Histórico e Oliveira Viana extrapolam a dimensão epistemológica ao abordar posições historiográficas que inevitavelmente demarcam perspectivas político-sociais importantes para aquela ambiência, desde que percebidas a partir da lógica da "retórica da neutralidade".

A recepção positiva da obra de Oliveira Viana no cenário intelectual nacional aparece como a oportunidade necessária para que certos sócios do IHGB busquem nela a atualização, ao menos no plano normativo, dos seus métodos, dos seus problemas investigativos e dos seus procedimentos de pesquisa. A aproximação com as reflexões de Viana pode ser a oportunidade institucional e epistêmica para se posicionar as atividades do grêmio na vanguarda do saber histórico pensado (e executado) naquele contexto. O recrutamento do estudioso carioca pelo IHGB é fato e indicador de uma 
espécie de "julgamento de relevância de uma agenda de pesquisa, assim como das formas de sua execução". As suas contribuições, atualizadas disciplinarmente, tornamse provocativas em termos de um saber regrado por pares, pois impacta uma "cadeia hierárquica de formação e reprodução [de saber] nesse espaço relativamente autônomo", isto é, o IHGB (TURIN, 2016, p. 5).

No início do seu discurso, como forma de demonstrar o seu conhecimento acerca das atividades, dos interesses e dos desejos daquele Instituto, Viana vale-se de algumas ideias do orador da instituição, Ramiz Galvão, considerado um mestre insuperável tanto nas "letras clássicas" quanto nas "letras históricas". As palavras que Viana recupera de Ramiz para iniciar a sua preleção, e porque não para se inserir em um campo discursivo específico e ordenado, caminham no sentido do reconhecimento dos seguintes desejos epistêmicos presentes nos trabalhos daquela agremiação: 1) o IHGB deve contar com agentes versados em todas as especialidades intelectivas, na medida em que a história, a geografia e a etnografia, na visão Ramiz que se replica na postura intelectual de Vianna, compreendem espaços de trabalho "vastíssimos"; 2) capacitar, então, os seus "obreiros" no exercício do "talento" e da "cultura universal" para a consecução do grande "livro da pátria" (uma nova história geral do Brasil?); 3) a concepção de história desenvolvida no Instituto envolve múltiplas questões, o que exige, necessariamente, "variados ramos do saber humano. Ela é a mestra e todos nós lhe prestamos reverência e subsídio" (VIANA, 1924, p. 433). Oliveira Viana aponta, tornando a sua voz uníssona com a de Ramiz, que essas demandas tornam a tarefa do Instituto Histórico uma das mais complexas em termos de elaboração de conhecimento, posto que a grandiosidade dessa obra, que necessariamente passa por um trabalho de cooperação coletiva, exige um perfeito espírito de excelência condizente com a própria tradição do grêmio. Ressaltando que o chamado "grande livro da pátria" apresenta-se como uma demanda cada vez mais desatualizada para parcela significativa da intelectualidade da Primeira República. Mesmo assim o IHGB tende a ser o maior centro cultural do Brasil. Há, certamente, outras instituições no país autorizadas no estudo das transformações históricas, doravante o Instituto

não só é a mais venerável e a mais austera como mesmo a mais compreensiva e menos especializada - pois o estudo da História, abrangendo hoje todas as especialidades, pede a colaboração de todas as ciências: as ciências naturais, as ciências do homem, as ciências da sociedade (VIANA, 1924, p. 433).

Qual o significado dessa concepção de história naquele contexto discursivo-disciplinar? Em que medida Vianna sugere um "lance" inovador em termos de epistemologia da 
história? Qual o sentido dessa fala entre os sócios do IHGB, inseridos que estão em diferentes modos de se estruturar a história? Ele cria uma memória disciplinar face aos importantes esforços e contribuições dos historiadores oitocentistas? O autor das Populações meridionais do Brasil (1920) almeja uma história total? Quais as habilidades, os requisitos e os princípios necessários para tanto?

De qualquer forma, amparando-nos inicialmente na dissertação de Ivan Norberto Santos, há, também, distanciamentos entre as iniciativas do IHGB e os desejos historiográficos de Oliveira Viana, que podem ser apreendidos através do caráter científico requerido pela disciplina na passagem para o século XX. Assim, alguns dos dispositivos considerados determinantes para o estabelecimento da cientificidade da história apontam para uma concepção de ciência que tem como finalidade última a descoberta dos elos e dos encadeamentos entre os acontecimentos, permitindo, ainda que em um momento futuro, a descoberta de leis (SANTOS, 2009, 47-48), como é mais corrente no IHGB e entre os egressos da Escola de Recife. É uma disposição teórica evolucionista em um registro prático historicista. Já Viana deseja o desvelamento das condicionantes múltiplas da determinação histórica ao fomentar uma concepção de ciência e mesmo de leis diferentes. Estas possuem caráter de representação não mimética em seu registro performático. Não é mais o processo de adequação das formas. Notamos que este discurso evidencia o intelectual substituindo, gradativamente, o vocábulo lei por tendências e por determinantes, retirando o grau factual e absoluto daquela antiga noção em favor de uma abordagem mais representacional e condicional.

Viana promove uma atualização epistêmica junto à ordem do discurso que enreda parte das atividades cognitivas dos sócios do IHGB. A dimensão científica da história operada pelo intelectual carioca é definida por meio da possibilidade de se alcançar, a partir dos eventos, a abstração através da síntese, isto é, por meio da generalização sociológica, com ênfase na psicologia social, que permite ir além da factualidade, revelando, então, as suas tendências representacionais subjacentes. É uma concepção de síntese diferente da que vem sendo operada com mais frequência entre os historiadores do Brasil, em que se observa a acumulação empiricista e a sugestão da sua abordagem teórica apenas no futuro. Uma dimensão sobrevivente daquilo que chamamos de sínteses historicistas (OLIVEIRA, 2020). Essas sínteses, para entendermos, negam a noção de lei ilustrada racional aceitando a noção de lei científica dos evolucionistas. Cabendo assinalar que as ciências sociais monocausais clássicas (Spencer, Taine, Haeckel, Ratzel) oferecem sobrevida a essas formas de sintese através da descrição naturalística, e supostamente científica, das leis fundamentais da história 
de modo a se efetivar conceituações que derivam em princípios (sociais) que potencializam o entendimento causal da individualidade das épocas passadas. É um processo de apropriação seletiva, pois os historicistas negam a universalidade das leis evolucionistas. Salientamos, de qualquer forma, que as sínteses historicistas interditam o "providencialismo clássico" e o racionalismo, posto que essa postura de pensamento não se modula como fruto de observações e de princípios lógicos ditos objetivos e seguros, além de apenas ligar narrativamente os eventos históricos. O "racionalismo" é concebido como resultado de projeções "idealistas" que se formam nas categorias do espírito para serem sobrepostas à realidade, da forma como percebido em certas sínteses ilustradas pioneiras. É exatamente aqui que se encontra outra diferenciação entre o conteúdo da noção de lei entre certas formas de síntese ilustrada e as historicistas e evolucionistas. Essa dupla interdição assinalada também é apreendida pelas sínteses modernistas.

É necessário dizer que a dimensão teórica do evolucionismo se dirige a uma tentativa de efetivação de enquadramentos deterministas sobre aspectos próprios da realidade histórico-social. Essa disposição, continuando, atualiza a sínteses denominadas de historicistas no sentido de exposição do universo histórico-social por meio de um encadeamento monocausal de sentido considerado científico. A recepção desse ideário pode ser encontrada, especialmente, em Tobias Barreto, Sílvio Romero e Fausto Cardoso. É necessário, contudo, perceber que os historicistas aceitam a noção de lei em âmbito regional, negando a generalização evolucionista. Porém, se deseja cada vez menos, na República, a exposição das leis científicas fundamentais que movimentam o processo histórico, mas se requer aquilo que condiciona as estruturas e as ações sociais.

As sínteses dos historicistas, em busca da valorização da individualidade das épocas passadas, possui maior pendor descritivo, como pode se ver, por exemplo, na importante História geral do Brasil (1854) de Francisco Adolfo de Varnhagen. As sinteses evolucionistas, preocupadas com a sucessão e a coexistência dos fatos, articulam-se pela nomologia, como se vê em Concepção monística do Universo (1894), de Fausto Cardoso. Já as sínteses modernistas, em direção das condicionantes sociais em nível representacional (mental), possuem maior inclinação explicativa, como nas Populações meridionais Brasil (1920). Quando os historicistas elevam a descrição ao plano teórico geralmente o fazem por meio de princípios causais de fundo filosófico e sociológico, mas não universais como em certas sínteses ilustradas e evolucionistas. Eles são encontrados, por exemplo, na economia política e no direito. Mais tarde, por 
volta da década de 1860 e 70, é o grande momento das sínteses evolucionistas informadas por uma sociologia monocausal. Já os modernistas também avançam pela via sociológica, porém, através do movimento de passagem, que sugere a permanência de resíduos, do evolucionismo ao "condicionalismo", que pode implicar até mesmo em um "condicionalismo organicista", como visto em A América Latina: males de origem (1905), do médico e educador Manoel Bomfim. O sentido teórico das sínteses evolucionistas ambiciona a efetivação de uma teoria unitária do social, enquanto que entre os modernistas verifica-se o desejo por uma espécie de coordenação de diversas teorias sociais parciais do social. Quando uma lei é apreendida pela ciência evolucionista torna-se possível conceituá-la, derivando, daí os princípios científicos. Se deve ter em mente que as sínteses evolucionistas funcionam, como uma espécie de face de Janus da moderna historiografia brasileira, pois atualizam a síntese historicista ao mesmo tempo em que anunciam a síntese modernista, sem deixar, obviamente, de conter as suas especificidades de cariz ilustrado. De qualquer modo, entre os modernistas, como no caso de Viana, encontra-se disponível, em meio aquele contexto epistêmico-discursivo do alvorecer republicano, o procedimento da retrospecção, divergindo das formas de história evolucionista. Esse dispositivo quer tornar obsoleto o mecanicismo da ciência de marca historicista-evolucionista.

Argumentamos que essas transformações não são abruptas e absolutas. Pensemos no caso dos Sertões, de Euclides da Cunha, que se situa entre resíduos das sínteses evolucionistas (nomologia e determinismo) e promessas das sínteses modernistas, como na forma literária, que no caso do ensaio em questão vale-se de metáforas e de antíteses de modo a aplainar o descritivismo da sua autopsia. É o famoso "consórcio entre ciência e arte" tão forte em sua recepção crítica. Ademais, os determinismos no texto euclidiano são desafiados pela consciência do imponderável, bem como pela presença de certo dualismo que evidencia contradições e polaridades na experiência da história nacional. Que fique claro: não há uma sequência temporal rígida na determinação das formas disponíveis de síntese, mas um processo dinâmico de atualização e de desatualização dos seus elementos em que se observa o fenômeno da coexistência.

Cabe deixar bem evidente que os desejos de Viana e de parte importante dos sócios do IHGB que o querem como sócio se coadunam em direção do reforço na superação de uma história episódica, como é prescrita em seus estatutos (coligir, metodizar etc.). Para esses sujeitos a história não deve se contentar com o registro factual. É necessário ligar, então, os acontecimentos, agrupá-los, classificá-los, explicá- 
los, para se extrair lições do passado sinteticamente. Assim, o saber científico, e neutro, produzido por essa parcela dos sócios do IHGB, e por Viana, adquire grande utilidade para o entendimento de uma desejada identidade nacional-patriótica na década de 1920.

\section{Os andaimes das sínteses modernistas: pluricausalidade, complexidade e interdisciplinaridade}

Um dos aspectos prescritos por Oliveira Vianna, que está ligado a sua ideia geral de história e de historiografia, diz respeito ao movimento pluricausal envolvido no desenvolvimento dos acontecimentos históricos, quer dizer, os "modernos historiadores" possuem a consciência de que os fenômenos históricos não se modulam a partir de uma cadeia evolutiva com feições progressistas, ou seja, eles não são resultados, pois, de uma mecânica causal total em que determinado elemento do passado é explicado por intermédio de um olhar que o localiza entre um natural antes e depois. Segundo as palavras do intérprete do Brasil: os fenômenos históricos são

extremamente complexos, resultantes, que são, da colaboração de uma
infinidade de causas, tão variados e múltiplos que, embora utilizando
as luzes de todas as ciências, e aparelhada com incontáveis métodos
de pesquisa a crítica histórica não consegue discernir senão uma certa
parte deles, que nem sempre, aliás, é a maior parte (VIANA, 1924, p.
439).

O seu parecer é inequívoco e através da leitura das prescrições do filósofo Henri Berr, que no mesmo período depara-se com problemas epistêmicos parelhos em França, articula-se no seguinte sentido: a complexidade fenomênica implica, necessariamente, a diversidade do saber. E Oliveira Viana possui uma imagem elucidativa que sintetiza esse percurso intelectivo: o historiador deve possuir as virtudes e as habilidades epistêmicas próprias do "enciclopedismo de Aristóteles". Isso tudo traz consequências diretas para a elaboração do conhecimento histórico, na medida em que as sínteses históricas, tomando como ponto de partida estas resoluções teóricas, possuem melhores condições de emergência caso se efetive um espaço de trabalho coletivo, assim como os membros do Instituto Histórico vem fazendo desde a sua fundação, em 1838, e Berr em torno do seu projeto editorial e intelectual em França. Mas há uma nova demanda para o IHGB: não se busca o trabalho coletivo visando o acúmulo de conhecimento factual, mas se quer construir um acervo de saberes, o que resulta em uma postura interdisciplinar, favorecendo o trabalho em equipe.

Há a consciência entre diversos intelectuais das primeiras décadas republicanas de que o "conhecimento de alguma forma lida não só com simplificações, mas 
principalmente com complexidades". Mesmo que em diversas normatizações a ciência apareça com a ambição de simplificar a complexidade, a estupefação frente ao âmbito da natureza e a dificuldade no estabelecimento de regularidades miméticas orientadoras das ações humanas podem ser encontradas nas reflexões de diversos intelectuais modernistas que são sócios do IHGB, entre os quais Euclides da Cunha, Oliveira Lima, Alfonso Taunay e o próprio Viana (IUMATTI; VELLOZO, 2013, p. 34).

Esse esforço intelectual não significa apenas um olhar institucional sobre o saber histórico, porém, toda uma forma específica de concebê-lo e de elaborá-lo. Todas as ciências, de acordo com as proposições de Oliveira Viana, concorrem para a consecução dessa tarefa cognitiva, porque os elementos que acompanham o desenvolvimento das sociedades realizam-se a partir do prisma da multiplicidade, ou seja, impossível de serem classificados e compreendidos sem o suporte epistêmico de todos os sistemas de conhecimento disponíveis. Isso equivale a "dizer que o mais simples fenômeno histórico exige para a sua exata compreensão os subsídios de todas as ciências naturais, de todas as ciências antropológicas, de todas as ciências sociais" (VIANA, 1924, p. 439). Em se tratando de abordagens historiográficas propriamente ditas, preocupadas com a caracterização social do humano no tempo, o mais adequado é a aproximação com essas últimas ciências, visto que não é possível desenvolver uma interpretação razoável acerca do processo histórico sem o concurso dos seus métodos, das suas questões e, também, dos seus dados objetivos.

Nesse sentido, Oliveira Viana admite que há a possibilidade de racionalizar, derivando disso constantes, permanências e continuidades que se replicam em contextos variados, disposições identitárias comuns, que ele denomina de "leis gerais" reguladoras das sociedades. Essas leis não são resultantes de uma tradução fiel de uma evolução mecânica de um grau inferior, menos desenvolvido, para outro mais complexo ou sofisticado como no caso das sínteses evolucionistas, visto por exemplo em Fausto Cardoso (1894). Elas são próprias de um regime científico diferente, cuja ambição repousa na análise das condicionantes das estruturas sociais. De acordo com o entendimento de Oliveira Viana, existem evoluções, ou melhor, variações evolutivas que podem até se cruzar; derivando, então, formas de desenvolvimento histórico diversificadas em suas estruturas organizacionais. No entanto, é possível em nível hipotético-dedutivo construir quadros teóricos que, de alguma maneira, tornam-se capazes, ao menos em nível explicativo, de abstrair "determinantes" inscritas nesse movimento plurievolutivo do devir. As leis são, para Viana, elaborações teóricas que traduzem recorrências histórico-sociais de modo representacional, operação distinta da 
nomologia. O desafio da ciência da história é, segundo a sua abordagem, superar o procedimento próprio das sínteses evolucionistas que equaliza a mobilidade própria do devir a partir de uma perspectiva intelectiva que vislumbra os fenômenos sociais, ou históricos, passíveis de serem apreendidos por uma grade de leitura que ressalta a imutabilidade, o fixo e o absoluto. Nesse horizonte investigativo o enredamento relacional das formas sociais, ou o estabelecimento das leis científicas, é determinista, direcionando-se evolutivamente sobre todo e qualquer fenômeno. Ademais, é a passagem do fato que traz em si uma totalidade fenomênica, como nas sínteses historicista, para o fato que possibilita a abertura para uma totalidade conceitual, como apresentado pela sínteses modernistas. Obviamente que as sínteses, a qual chamamos de modernistas, não desenvolvem uma atividade cognitiva meramente abstrata. Elas derivam de uma escrupulosa pesquisa empírica, atravessada pelo rigor metódico e atenta às particularidades. Esse movimento é a sua propedêutica.

A elaboração de um saber total, tal como é concebido pelas sínteses ilustradas do século XVIII e início do XIX, encontra-se na passagem para o século XX em estado de obsolescência, tanto no âmbito teórico quanto no prático das pesquisas em história. $\mathrm{O}$ saber possível naquele momento é o que privilegia as monografias, sendo o século passado o dos "especialistas", ainda que de um tipo próprio de especialista: "aqueles que conseguiam interpretar e relacionar temas particulares a fatos gerais" (IUMATTI; VELLOZO, 2013, p. 40), o que abre margem para um circuito de conhecimento interdisciplinar. O que podemos reter disso tudo é a desatualização paulatina das antigas, e pioneiras, sinteses ilustradas, mas a dimensão total da história não sendo abolida integralmente pelo modernismo. Assim, a inicial impossibilidade da totalidade pode até ser aceita, mas a perspectiva monográfica deve ser compatibilizada com a atenção aos códigos gerais de funcionamento societário ou aos fatores de orientação geral, concebidos na forma de representação e em uma perspectiva de totalidade conceitual, o que oferece condições de possibilidade paras as novas sínteses históricas, por nós assimiladas como modernistas.

Viana reage, desde a década de 1920, contrário às formas unilineares de entendimento da evolução das sociedades. Mobilizando a original sociologia de Gabriel Tarde o intelectual carioca considera existir "múltiplas tendências" envolvidas na evolução das sociedades, sendo impraticável reduzi-las a uma única perspectiva esquemática. Assim, existe, em ciências sociais, o "heterogêneo social" de Tarde em contraponto ao "homogêneo social" de Herbert Spencer. No estudo histórico das sociedades encontra-se, como quer Oliveira Viana, uma verdadeira multiplicidade de 
frentes de evolução e de fatores que interferem nas mesmas. Para o entendimento dessa dinâmica concorre uma variedade de séries evolutivas. Junto ao heterogêneo social apropriado de Tarde intervém fatores de toda a ordem em uma dinâmica complexa, entre eles os advindos da terra, do homem, da sociedade e da história; transpassados por fatores étnicos, econômicos, geográficos, históricos e até mesmo climáticos. "Estes predominam mais na evolução de tal agregado; aqueles, mais na evolução de outro, mas, qualquer grupo humano é sempre consequência da colaboração de todos eles; nenhum há que não seja a resultante da ação de infinitos fatores, vindos, a um tempo, da Terra, do Homem, da Sociedade e da História (RODRÍGUEZ, 2003). Esse consórcio de saberes é apurado, discriminado, isolado e cruzado, de modo a conceber os caminhos da interdisciplinaridade junto ao fomento das sínteses modernistas. Todas aquelas teorizações que embasam a compressão da evolução das sociedades a partir da ação de uma causa única são gradualmente, dos 20 anos aos 50, desatualizadas por Oliveira Viana. Chega-se, então, a seguinte conclusão, que se sedimenta em seu ideário de pesquisa ao longo de toda a sua carreira: não há monocausalidades em ciências sociais.

Não é incomum, tendo em vista essas três condições para as sínteses modernistas, isto é, a pluricausalidade, a complexidade e a interdisciplinaridade, resguardar esse procedimento epistêmico para o futuro. Para um momento em que "todos os casos particulares, irredutíveis a qualquer padronização ou descrição por tendências que dispersem seus estudos individuais, tenham sido conhecidos". O momento parece ser "de análise (literalmente, de separação em partes) para depois se elaborar a síntese" (NICODEMO, SANTOS, PEREIRA, 2018, p. 63). Essa consciência epistemológica residual é derivada das sínteses historicistas. É uma herança práticohistoriográfica oitocentista e, ainda, presente nas atividades, por exemplo, dos sócios do IHGB nas primeiras décadas republicanas. Além disso, essa postura provém da renovação dos fatos enquanto totalidades processuais, como visto da história geral de Varnhagen, para fatos igualmente totais, mas interdependentes a partir do registro das sínteses evolucionistas, da forma como desejado por Capistrano de Abreu em sua "fase" cientificista. Essa propensão teórica não visa a abstração representacional da realidade histórico-social, mas teoriza causalmente os fenômenos até a efetivação de uma ordem fixa e que se pretende permanente, necessitando, em história, do maior domínio empírico possível. Mas é por meio do evolucionismo que se intensifica a cientificização da história. No Necrológio de Francisco Adolfo de Varnhagen (1878) há uma atualização da sínteses historicistas, exemplificadas através da obra do Visconde. A síntese percebida neste opúsculo, dita evolucionista, lega aos modernistas a consciência 
empática, compreensiva e objetiva (validade) do conhecimento a partir de um aprimoramento de disposições próprias das sínteses historicistas.

Mas a demanda sintética por levantamentos extensivos e críticos de informações históricas relaciona-se, também, com o intento de fechar reflexivamente as lacunas empíricas que a consciência da pluricausalidade deixa na urdidura de intriga própria dos historiadores pela retrodicção, em que a complexidade impõe ao sujeito cognoscente um "olhar sinóptico" (DETONI, 2019) em sua abordagem sobre a experiência do tempo, o que requer, sendo grande a abertura para o real que a postura explicativa oferece aos "obreiros" de Clio, que as pesquisas passem por uma substantivo processo de apuração a partir de uma perspectiva disciplinar plural. Esse movimento do saber, para suprir os reclames das sínteses modernistas, não deve se ater à dimensão acumulativa (fenomênico-empírica) do conhecimento histórico como herdado do passado dos fundadores do Império, mas avançar junto ao plano teórico, explicativo e reflexivo. Diferenciando-se, também, do sentido monocausal almejado pelas histórias filosóficas de marca romântico-ilustradas, como a de Von Martius. As sínteses historicistas e evolucionistas alegam que as histórias filosóficas, formada por elementos das sínteses ilustradas, carecem de princípios lógicos e de direção científica. Se um fato histórico movimenta toda uma totalidade processual entre os historicistas e os evolucionista, o evento modernista abre uma dimensão espectral da experiência só apreensível (e parcialmente) por induções (ou retrodicções) conceituais (DETONI, 2013). As condições de possibilidade para a emergência das sínteses modernistas relacionam-se com as mutações das sínteses evolucionistas em uma espécie de espectro explicativo em ciências sociais. Nesse "espectro" as linhas evolucionistas também se dispõem, é bom lembrar, em modo regressivo. Não é incomum que se chegue a essa consciência epistemológica sobre o plano da temporalidade através da realização de um processo de leitura que complexifica os autores evolucionistas pluralizando pela retrodicção as linhas de causalidade por eles abordadas, como é o caso de Oliveira Viana. Para esses sujeitos as sínteses modernistas podem ser realizadas no presente, não se perdendo em promessas futuras. $\mathrm{O}$ ensaio histórico é a sua forma narrativa por excelência.

O que eu gostaria de reter é que os três andaimes das sínteses modernistas (pluricausalidade, complexidade e interdisciplinaridade) esperam complexificar especialmente as sínteses evolucionistas monocausais que alimentam diversas teorias de inspiração e de matriz cientificistas (WEHLING, 2001) sobre a formação históricosocial no decorrer da segunda metade do século XIX em uma direção espectral. O "espectro pluri-evolucionista" também se movimenta regressivamente. É um vai e vem 
nas linhas de causalidade que denota condicionamento. A dimensão reflexiva empregada por Oliveira Viana em seus trabalhos também parece notável, sobretudo, se pensarmos no ethos do historiador que se orienta pelo "gosto do arquivo" (GOMES, 1996) que corre no alvorecer republicano, exemplificado pela figura de Capistrano (OLIVEIRA, 2013). As sínteses modernistas resultam da passagem das sínteses evolucionistas, que oferece sobrevida à resíduos das sínteses historicistas, para uma espécie de pluri-evolucionismo incorporador do circunstancial inscrito no âmbito do movimento da ação social. Isso pode ser verificado através da formulação de uma ampla tipologia sobre a experiência da história movimentada por Viana, percorrendo o período colonial até as primeiras décadas republicanas, no decorrer de toda a sua obra.

O discurso de posse de Oliveira Viana no Instituto Histórico é capaz de nos apresentar o seu espírito investigativo, diferente do cientificismo oitocentista, se revelando através de um aporte teórico-metodológico que se quer rigoroso para a formulação de noções e de categorias tanto psicossociológicas quanto historiográficas extraídas, pois, da observação da realidade, bem como da comparação entre subsídios experienciais. Não deixa de ser importante frisar, contudo, a baixa empiria presente em suas pesquisas. Mas Oliveira Viana parece alguém que, de fato, sabe os caminhos que a investigação deve tomar modernamente ao mesmo tempo em que é absolutamente infeliz em suas escolhas, como no caso dos estudos étnicos, componentes de um projeto ambicioso que visa o entendimento dos seres humanos da dimensão social e cultural ao plano psicobiológico.

A proposta de síntese de Oliveira Viana é resultado de algumas décadas de esforços normativos realizados por intelectuais brasileiros desde ao menos a proclamação da República. Ela é o ponto de destino de toda uma transformação visível nos modelos e nos regimes historiográficos elaborados pelas gerações românticas que fundam o Império atualizados pelo evolucionismo clássico. Podendo ser entendida como um índice consistente acerca da riqueza de elaborações teóricas e práticas visíveis em uma experiência historiográfica que se situa na passagem dos evolucionismos explicativos clássicos para o ambiente universitário prestes a se afirmar no Brasil da década de 1940, mas que possui condições de existência e de autossustentação particulares, respondendo à problemas próprios e elaborando soluções dotadas de historicidade epistêmica. 


\section{Crítica, fontes e induções teóricas}

A disposição interdisciplinar passa a ser fundamental para um melhor aproveitamento da crítica metódica, habilidade indispensável para a averiguação da veracidade das informações que formam os inquéritos investigativos acerca de determinada experiência da história. Ademais, esse recurso amplia a noção de fonte histórica, que para Vianna não pode ficar adstrita ao universo da documentação arquivística e arqueológico, que por si só parece insuficiente para o esclarecimento do passado. Em uma ambiência marcada pela forte mobilização do regime historiográfico metódico, de empenho erudito na apuração e na transformação dos documentos em fonte de conhecimento seguro, as prescrições de Viana parecem invocar novas habilidades para o apuro da crítica, bem como para a problematização do estatuto da fonte histórica enquanto vestígio possível de uma dada realidade passada. Elas procuram atualizar o ethos do historiador "crítico de arquivo" e o seu próprio ideal de objetividade (NOVIK, 2008). Acompanhemos o seu parecer:

\footnotetext{
Os documentos não dizem tudo, não fixam tudo, não apanham todos os aspectos dos acontecimentos; dizem apenas alguma coisa, fixam apenas alguns detalhes, apanham apenas alguns aspectos - e, às vezes, esses aspectos, que eles revelam, nem sempre são essenciais; esses detalhes que eles fixam, nem sempre são necessários; essa coisa que eles dizem, nem sempre contém o sentido íntimo e substancial da realidade (VIANA 1924, p. 440).
}

Para o autor, as fontes para a realização do trabalho de "evocação do passado" não estão restritas à documentação nem à vestígios materiais. Os problemas investigativos que Viana se propõe a pesquisar movimentam-se em outra direção. Não estão ligados, por exemplo, a construção política de um Estado nacional, o que movimenta todo um trabalho de busca e de averiguação de fontes arquivísticas e de vestígios monumentais e arqueológicos, haja vista as primeiras movimentações do IHGB, mas relacionam-se com as dimensões próprias do mundo das ações e das estruturas sociais; o que, por seu turno, demanda novas modalidades de vestígios. No caso a ênfase recai sobre os involuntários. Também cabe sinalizar o seguinte: Viana não considera as fontes históricas uma espécie de espelhamento mimético do real, assim como Capistrano, exempli gratia, vem pensando desde ao menos a década de 70 em sua crítica ao historiador cronista (SANTOS, PEREIRA, 2010). As lacunas das fontes são, para o autor, constituintes da própria tarefa crítica, sendo necessário, então, trabalhar com o plano teórico e reflexivo, instância capaz de informar o invisível do passado. Mas não aquela instância teórica evolucionista que deriva na adequação das formas. $O$ estudioso argumenta que por mais que as fontes documentais sejam, no geral, ricas em 
informações sobre o passado, e mesmo sabendo que é o olhar do sujeito cognoscente que informa as dimensões da passagem do tempo no presente, elas não informam a totalidade do mundo fenomênico. Essa conclusão sinaliza que as fontes arquivísticas registram, em muitos casos, apenas uma camada superficial de uma dada situação histórica, não captando aquilo que Georges Cuvier denomina, segundo Oliveira Viana, de "caracteres dominantes".

Desse modo, para José Carlos Reis, a maioria dos historiadores do século passado, inclusive brasileiros, se apega a uma epistemologia prática: "observam o que a comunidade faz, e o conhecimento e a verdade possíveis são definidos pela própria prática histórica" (REIS, 2000, p. 323). A posição de Viana neste discurso é a de alguém que tem como objetivo desnaturalizar toda uma prática historiográfica que faz parte dos horizontes investigativos dos sócios da agremiação carioca a partir de uma postura teórica pós-evolucionista clássica. E isso ocorre nos níveis mais básicos de tal atividade: na expansão da variedade de fontes, na reflexividade possível junto ao material trabalhado pelo historiador desde o momento do arquivo e na consciência pluricausal que a narrativa histórica projeta no fechamento de lacunas conceitualmente. Talvez a sua posição de fala só seja possível pelo fato dele situar-se intelectualmente nas bordas daquela comunidade de historiadores dos anos 20, mesmo sendo recrutado pelo seu polo mais significativo: o IHGB.

O discurso de Viana, compassado a um movimento historiográfico de natureza Ocidental, coloca em dúvida a ciência historicista-evolucionista, aquela pautada pela ideia de princípios que traduzem o universo social por meio de leis (IGGERS, 1997). O que está em jogo para esses intelectuais americanos e europeus é a transformação da operação historiográfica em um procedimento explicativo que se quer rigoroso e perpassado por uma noção de ciência que já não se localiza no âmbito da adequação das formas. Um adendo: as sínteses modernistas são devedoras da transformação do naturalismo descritivo, como se percebe nas prescrição encontradas na História da Literatura Brasileira (1888), de Sílvio Romero, em uma objetividade circunstancial, como por exemplo em Evolução política do Brasil (1933), de Caio Prado Jr.. Dito isso, verifica-se que a concepção de ciência da história pós-evolucionista vale-se de uma ideia de falseamento não mimético dos produtos intelectuais produzidos por uma dada comunidade. Tal comunidade de historiadores existe no Brasil republicano, sendo percebida, por exemplo, pela recorrência de referências e de temas historiográficos, bem como pela existência de instituições normatizadoras, como o IHGB e os institutos regionais, e de figuras-chave, espécie de grandes orientadores, como é o caso de 
Capistrano de Abreu. Essa concepção de ciência, ou melhor, de ciência da história tem como eixo diretor a fundamentação teórico-prática, sendo capaz de promover explicações hipotéticas, amparadas em uma "boa" empiria, junto aos fenômenos do mundo da vida, informando-as reflexivamente. Nesse horizonte se inscreve o falseamento. Ela se ampara na ideia de objetividade como construção de um saber válido, dispositivo herdado dos evolucionistas. O que passa, também, a legitimar a prática historiográfica é a coerência axiológica: a compreensão dos acontecimentos históricos a partir da perspectiva valorativa (social, moral, mental, econômico).

Para se realizar, então, as sínteses modernistas, que não deixam de ser propostas de história total (em termos conceituais), Viana fala da necessidade, tendo em vista as insuficiências das fontes documentais, da realização de "induções conjecturais", vocabulário epistêmico que o estudioso de Saquarema apropria-se do historiador francês Ernest Renan, para quem a ciência da história constitui-se enquanto uma "pequena ciência conjectural". A utilização das habilidades conjecturais não destitui, para Oliveira Viana, o caráter científico da história, que em um primeiro momento pode parecer prejudicado desde que visto sob um viés empirista minimalista. Essa dimensão de conjecturalidade não é privilégio da história, incidindo tanto nos domínios das ciências da natureza como nos horizontes das ciências sociais. Cabe se ater, no entanto, para as duas formas de conjectura disponíveis: a "conjectura arbitrária" e a "conjectura disciplinada". Mas o que isso significava epistêmicamente? A primeira é própria, argumenta Viana, dos "velhos historiadores", modulando-se, em tese, através da imaginação e sem contato com a realidade histórico-social. Já a "conjectura disciplinada" é diferente: ela se orienta através dos quadros hipotético-dedutivos oferecidos pelas ciências sociais, especialmente a sociologia pós-evolucionista, problematizando uma dada ambiência história de modo a localizar representações (psicossociais). Estas agenciam experiências históricas, demarcando, então, o seu espírito "neorrealista" (a agencia da representação), de modo a serem apreendidas objetivamente, quer dizer, através da noção de validade do conhecimento, isto é, da coerência epistêmica. Assim, ela se orienta por meio das normas que condicionam, no plano teorético, as estruturas valorativas das sociedades. Ela é um princípio cognitivo de fechamento de lacunas factuais de modo conceitual, ampliando a percepção do real. Isso é relevante porque essa disposição hipotético-dedutiva serve para a retificação e para a ampliação da visão crítica, não apenas no sentido da "fantasia evocadora", mas para a reconstituição com o maior rigor científico possível da "estrutura" e da "vida" das "velhas sociedades morta". 
Portanto, o desenvolvimento da crítica histórica consiste não na suspensão da "indução conjectural", dado que isso implica na falência da própria crítica, mas na tentativa de redução do coeficiente subjetivo conjectural, quer dizer, na substituição gradativa da conjectura subjetiva pela outra considerada disciplinada, pois tem como disposição originária princípios objetivos, isto é, preceitos cognitivo-analíticos considerados e dispostos em modo de validação. Se quer superar as induções que se desviam para a subjetividade humana, local em que prevalece as simpatias, as paixões e os antagonismos temperamentais. O caminho aberto pela noção de "indução conjectural" adequada oferece "uma possibilidade única, e talvez inédita, de tratar a(s) sociedade(s) com objetividade isenta de pressupostos políticos e filosóficos" (BRESCIANI, 2007, p. 182).

Podendo se portar interdisciplinarmente, movimentando, assim, o âmbito reflexivo das ciências sociais (evolucionismos híbridos) em seu plano explicativo, a história mobiliza essa nova noção de conjectura colocando em evidência "contingentes de realidade" que não estão fixados no testemunho dos documentos. Esse registro historiográfico se orienta para aquilo que é invisível junto ao processo histórico, tornando o métier do historiador um trabalho de, apropriando-se de Michelet, "ressureição", quer dizer, uma verdadeira "arte literária" de tecelagem conceitual. "É assim, com auxílio dessa conjectura objetiva, que a crítica tem conseguido desvendar o mistério de certos enigmas, que apenas com os elementos arquivais lhe seria impossível esclarecer" (VIANA, 1924, p. 442). De qualquer maneira, o que oferece objetividade à “indução conjectural" é o fato dela ser uma atitude cognitiva própria de uma disposição de saber específica, qual seja, a síntese histórica, que requer rigor analítico e explicativo, do arquivo ao balanço das experiências humanas.

Mas para se chegar às sínteses modernistas Oliveira Viana se assume como um leitor do conhecido engenheiro politécnico francês Fréderic Le Play, posto que os seus estudos oferecem a direção das pesquisas metódicas e monográficas. Pode-se dizer que os exercícios monográficos servem a certas sínteses modernistas como análise classificatória. Se para o caso francês a abordagem e a observação dos comportamentos gerais dos agentes sociais de diferentes profissões e de várias áreas colonizadas levam Le Play a conduzir seu empreendimento científico em equipe (BOTELHO, 2002); Oliveira Viana, sem o concurso de outros estudiosos para os seus planos de estudo, imprime em sua investigação uma proposta de trabalho em etapas, "mas sempre com base nas mesmas premissas e seguindo um procedimento sistemático" (BRESCIANI, 2007, p. 198). Lembrando que Le Play é um evolucionista mais pluralista. A "indução 
conjectural", operação científica pautada pela objetividade explicativa, tem como intenção oferecer coerência e coordenação teórica aos resultados de pesquisa presentes nas monografias visando as sínteses modernistas, estruturas de saber defendidas pelo pesquisador brasileiro. Le Play está mais interessados na classe dos fenômenos históricos, sendo que o nosso autor se apropria do seu trabalho transcendendo certa empiricidade em si e para si. As monografias representam, em Viana, menos informação nomológica e mais um acervo de saberes.

A dialética entre monografia e síntese, como demonstrada em suas obras dos anos 1920, coloca em evidência que o povo brasileiro não é uniforme. Assim, deve-se conhecer a caracterização regional do Brasil para que daí, sim, se possa explicar e extrair uma síntese social e psicológica. A demanda por estudos monográficos representa, necessariamente, a diversidade regional brasileira. Por isso a monografia, a análise, é anterior ao registro sintético. Desse modo, para muitos autores, como Alfonso Taunay, contemporâneo de Viana, o momento da síntese ainda não havia chegado. Esse é um argumento sobrevivente das sínteses historicistas. Para essa perspectiva de saber, argumenta Karina Anhezini, "esse não era o momento de fazer a síntese, era sim a hora de aplicar os procedimentos e produzir monografias para o adequado estudo dos temas" (ANHEZINI, 2006, p.36). Mas as sínteses modernistas que circulam na República, inclusive a movimentada por Viana, requerem a atualização desse procedimento, que atravessa as sínteses evolucionistas, pois elas estão interessadas não no acúmulo de saber empírico, inclusive que deriva em leis científicas monocausais, mas, sim, em agregar relacionalmente saberes visando uma abordagem interpretativa interdisciplinar sobre este mesmo material, o que não deixa de ressaltar a heterogeneidade regional do país, que nessa perspectiva modula-se de maneira representacional.

A diferença normativa nesse horizonte sintético geral, garantidor dos balanços modernos das experiências humanas, é que o primeiro polo, as sínteses ilustradas, busca filosoficamente um sentido para o curso da humanidade, enquanto que o segundo polo é empiricista, acumulativo e causal, havendo a diferença entre os fatos totalidades processuais e a nomologia como "fotografia das leis", elementos das sínteses historicistas e das evolucionistas, já o terceiro polo, as sínteses modernistas, problematiza o material factual criticado pelo historiador fechando lacunas conceitualmente de modo regressivo. As sínteses historicista e evolucionista, por terem a consciência que o evento traduz uma totalidade processual, sugestiona a ampliação do pecúlio fenomênico (por empiria ou por nomologia). Esse horizonte sintético abrange um longo período que vai, aproximadamente, da passagem do século XVIII para o XIX 
até por volta da década de 1940. Percebemos nele um movimento de atualização e de desatualização dos seus elementos constituintes. Essa disposição permite um processo epistêmico de hibridação e de coexistência.

As sinteses modernistas avançam, de qualquer forma, reflexivamente diante da consciência da incompletude empírica. Ou seja, uma forma de entender a diferença entre as sínteses é por meio da consciência de que as versões historicistas e evolucionistas compreendem o passado, respectivamente, através do acúmulo empíricoinformativo, mesmo sabendo que a fonte não é um espelho da realidade, e pela projeção de leis científicas que pela fixação de aspectos da realidade amplia o entendimento da individualidade histórica em perspectiva passível de generalização. As leis dos historicistas, no entanto, são regionais, enquanto que as dos evolucionistas são universais. Já as sínteses modernistas entendem que é impossível atingir a totalidade da experiência da história, mas defendem que a teoria (pós-evolucionista), a constelação categorial, cobre e amplia as limitações do material empírico em um horizonte conjectural de sentido atravessado interdisciplinarmente. $\mathrm{O}$ fato modernista é irredutível a um sentido unitário de causa e efeito como é entre ilustrados, historicistas e evolucionistas. A proliferação de ensaios de interpretação histórica nas primeiras décadas republicanas demonstra a atualização gradativa nas formas de síntese.

Mas certos registros das sínteses historicistas que a atravessam a disposição evolucionista, ainda encontrados no alvorecer republicano, como entre parcela importante dos sócios do IHGB (HRUBY, 2007), demonstram, talvez, um conflito entre epistemologia e prática dentro daquele horizonte discursivo, dado que eles parecem atender a certas exigências historiográficas consideradas imprescindíveis, como no caso da não aceitação de certo mimetismo ingênuo das fontes e da constante reescrita do relato histórico, ao mesmo tempo em que se operacionaliza através de procedimentos técnico-cognitivos que passam a ser percebidos como obsoletos, como a adição de informação empírico-factual criticada que parte do particular para o geral causalmente, derivando, inclusive, em leis científicas fixas. Para nós ela traduz o desejo por uma nova história geral do Brasil, aparentemente com parâmetros teóricos informados pelas sínteses evolucionistas, em um momento que se demandam outras propostas epistemológicas, e narrativas, junto à prática do historiador. O efeito colateral percebido nesse descompasso é que esses resíduos da síntese historicista acoplados à perspectiva teórica evolucionista monocausal, no contexto da República, são responsáveis por sempre adiar a realização do chamado "grande livro da pátria", da forma como quer importante parcela dos historiadores do IHGB. 


\section{As virtudes (e os descaminhos) do olhar retrospectivo}

Além do âmbito teórico capaz de revelar novos vestígios do passado que complementam a análise das fontes de arquivo, mostra-se igualmente relevante a tomada de consciência que o trabalho do historiador respeita o procedimento retrospectivo: a noção de que as sínteses modernistas partem de problemas do presente em uma direção dialética ao passado. Assim, Lilia Schwarcz argumenta na seguinte direção: "conforme chegamos aos primeiros anos do século atual [o XX], uma nova forma de entender a história começa a preponderar. Escrever a história nacional significava, também, tomar parte de um debate que levava a análise do período contemporâneo (...) (SCHWARCZ, 1989, p. 31). A observação da realidade apresentase capaz de suprir as lacunas da "velha crítica" e das conjecturas arbitrárias operadas por muitos dos nossos historiadores. Viana acredita ser possível localizar muitas analogias explicativas na observação objetiva da sociedade contemporânea, como no caso da comparação entre o "bandeirismo" e o "feudalismo guerreiro". De qualquer forma, assevera o autor que "os textos dos nossos arquivos, à luz desses elementos, extraídos da observação, à luz dessas 'experiências complementares', para empregar uma expressão feliz de Davy, adquire uma vida nova e uma nova claridade" (VIANA, 1924, p. 443)!

A síntese modernista proposta por Oliveira Viana em seu discurso de posse no IHGB prescreve o desenvolvimento de uma "metodologia retrospectiva" em que se verifica uma nova dialética entre o presente e o passado. Nessa forma específica de pensar a história não se pode negligenciar o presente que circunscreve o sujeito cognoscente. Ele necessita visualizar o seu em torno, conectar-se com os problemas do seu presente, para, por meio dele, inquirir e explicar a experiência histórica. Nessa perspectiva de história o passado deixa de ser substantivo para performar-se enquanto adjetivo. Em última instância, o passado não é produto inteligível fora de uma cadeia de problematizações mobilizadas pelo presente. Por isso a história, conforme passagem conhecida de Marc Bloch, une o estudo dos mortos ao dos vivos (BLOCH, 2001).

É inevitável aproximar essa perspectiva acerca da relação passado-presente à historiografia dos annales. Uma coisa é certa: há proximidades epistemológicas entre Viana e os historiadores franceses, porém, isso é derivado de movimentos historiográficos que possuem identidades próprias, mesmo que se entrecruzem em alguns pontos a partir da perspectiva da comparação. A forma como José Carlos Reis caracteriza o olhar retrospectivo mobilizado pelos primeiros annales nos faz pensar esse 
modo de encarar o tempo por parte de Viana e de alguns dos seus coevos. Segundo Reis, no olhar retrospectivo, em que há a relação passado-presente, o que percebemos são polos temporais diferentes que dialogam, havendo um relacionamento de interrogação recíproco. Nessa dinâmica, o presente não se apresenta como um continuador ou como um estágio superior ao passado. Ele é "outro". Desse modo, o olhar retrospectivo, tão invocado por Bloch, não transporta o historiador às "origens". O que se observa é uma dialética ativa, isto é, o historiador transita do presente ao passado e retorna do passado ao presente. "O historiador não pode ignorar o presente ao qual pertence - deve ter a sensibilidade histórica do seu presente e interrogar o passado a partir dele. Ele faz o caminho do mais conhecido, o presente, ao menos conhecido, o passado" (REIS, s/d, p. 66). De todo modo, o olhar retrospectivo incitado pelo sujeito cognoscente historiador possui um interesse vivo pelo passado, dado que se quer compreendê-lo enquanto continuidade e como diferença. Assim, atualiza-se os modos evolucionistas de apreensão da realidade histórica que se performam através da origem das origens, bem como por meio de uma disposição mecânica passado-presente-futuro. O historiador efetua um vai e vem no tempo: do presente ao passado e retornando do passado ao presente. Passado e presente se adjetivam reciprocamente. Esse movimento coloca em estado de obsolescência várias modalidades evolucionistas monocausais clássicas correntes e relativamente atuantes na passagem para o século XX. Existe a consciência de que há pluralidade evolutiva (espectral) que se performa, igualmente, no registro regressivo.

Nessa perspectiva, sobretudo, a sociologia e a antropologia amparam a síntese modernista de Viana. No caso da antropologia, que se conecta interdisciplinarmente com a história, a importância analítica recaí, da forma como pensada por nosso autor, sobre a formulação de uma "morfologia étnica" das camadas sociais. Ela, servindo à história no âmbito explicativo, revela questões do passado aparentemente invisíveis. Viana argumenta que é certo que a hereditariedade étnica não satisfaz, como quer Lapouge e a sua escola, a explicação da complexidade do tecido social, porém, também é bastante evidente que sem esse componente torna-se impossível compreender e explicar cientificamente a história de qualquer nação, visto que é uma "poderosa determinante da conduta humana" (VIANA, 1924, p. 443). Os problemas historiográficos estão, nesse sentido, à espera das pesquisas acerca da "morfologia raciológica" atual; capazes de por analogia evocar o passado em uma perspectiva que chega a incidir sobre os corpos dos agentes históricos. Ricardo Sequeira Bechelli assinala que no decorrer da sua obra, tendo como ápice Raça e assimilação (1932), o 
escritor fluminense chega a enfatizar os estudos raciológicos e de diferenciação entre os seres humanos a partir da justificativa de que há diversidade de inteligência e de mentalidade (BECHELLI, 2009, p. 326). A observação morfológica no presente, em que se sugestiona, por exemplo, o branqueamento racial (arianização), é o suporte para um olhar racial regressivo. Essa postura lhe serve para enfatizar a sua teorização acerca da diferenciação entre os seres humanos em termos de inteligência e de psique. Oliveira Viana, ao defender a noção de diferenciação racial, concebe as ideias dos "igualitaristas raciais" como preconceituosas no que tange à orientação de que as "raças" tendem a ser diferentes não apenas anatomicamente, mas, sobretudo, no comportamento psicológico. Cabe dizer que esse paradigma psicoantropológico mobilizado pelo intelectual carioca é negado nesse momento por não poucos intelectuais, como, por exemplo, o conhecido antropólogo Edgar Roquette-Pinto. Essa perspectiva de saber está longe de ser uma novidade ou inovação epistemológica. Bechelli nos apresenta uma consistente amostragem acerca do estudo de "morfologia regressiva" operado por Oliveira Viana:

\footnotetext{
Ele trabalha de uma forma bastante acentuada na questão dos caracteres físicos resultantes dos cruzamentos raciais e como os preconceitos sociais, em resultado da aparência física, impediam o crescimento e o desenvolvimento. No caso do mestiço do branco com o índio, Vianna vê uma possibilidade maior de desenvolvimento, uma vez que têm características físicas do homem branco, tais como o tom da pele e o cabelo liso (sinais de "pureza racial") (BECHELLI, 2009, p. 319).
}

A retrospectiva deve se amparar teoricamente em um suposto conhecimento da realidade presente, da realidade circundante, em compasso com as ciências da natureza e da sociedade (biologia, antropologia, geografia, sociologia, etc) para a compreensão do passado, para a reconstituição das sociedades extintas. "Sem esse conhecimento preliminar, sem as luzes de todas essas ciências das realidades vivas, é impossível a ciência das realidades mortas, reveladas pelo testemunho dos arquivos" (VIANA, 1924, p. 444). São as ciências das realidades vivas, diretoras do olhar retrospectivo, que estudam a complexidade dos fenômenos históricos, isto é, a partir do solo, do clima e do homem, revelando os segredos da "vida orgânica" e "superorgânica", dando nova orientação às fontes documentais e uma vida nova aos depoimentos "fixados nas páginas mortas dos arquivos" e "uma tal sonoridade que, lendo-os, é como se estivessem a ouvir a voz dos nossos próprios antepassados" (VIANA, 1924, p. 444). Porém, essa postura leva Viana, inevitavelmente, a cair no grande pecado do "racismo científico" em nome de um suposto estudo de "morfologia étnica" visando a tradução das representações psicorraciais dos sujeitos em sociedade através do tempo. Além disso, o seu argumento acerca da diversidade das raças tem um claro apelo eugênico. 
Mas a interdependência entre a história e as demais ciências provoca no "moderno historiador" a necessidade da sua identificação com o espírito do seu tempo. Se quer superar certa figuração de historiador alheio ao universo simbólico que o enreda; que se ocupa tão somente com o passado pelo passado na trilha das fontes documentais. $\mathrm{O}$ que não significa se entregar às paixões. $\mathrm{O}$ historiador de Viana, que congrega em si demandas epistemológicas postas ao métier na década de 1920, deve estar atento a tudo ao seu redor, desde as pequenas até as grandes verdades que vem dos mais inesperados lugares. Essa é uma postura de quem procura vestígios involuntários.

O conhecimento demandado por Viana requer o concurso de diversas disciplinas sociais e da natureza, posto que a "luz das suas revelações que ele [o historiador] prepara e realiza o prodígio das suas sínteses e o milagre das suas ressureições" (VIANA, 1920, p. 444). Por isso, deve-se compreender que as diversas orientações das ciências em geral passam a ser incorporadas ao seu trabalho de reconstrução do passado através de um processo ativo de apropriação, o que nos faz entender como Oliveira Viana dispõe de uma inovação epistemológica, o olhar retrospectivo, ao mesmo tempo em que ainda se orienta através de resíduos de paradigmas raciológicos evolucionistas obsoletos, sobretudo, a partir da leitura de Georges Vacher de Lapouge (e até Gobineau), e mantém o seu posicionamento político ao lado do "autoritarismo instrumental" (SANTOS, 1978). Uma questão de escolha? Talvez possamos dizer que há inovação epistemológica em Viana ao mesmo tempo em que se verifica uma desatualização em termos, por exemplo, da mobilização de paradigmas raciológicos em razão daquele desejo pela representação biossocial dos agentes sociais. Ou ainda: as ciências sociais mobilizadas por ele como teoria da história não estão no mesmo compasso das transformações epistemológicas visíveis na década de 20, próprias das sínteses modernistas que ele mesmo defende como plataformas de saber. É uma aparente contradição: o autor das Populações meridionais do Brasil (1920) se vale do recurso da retrospecção, assume a pluricausalidade e a complexidade em história, ao mesmo tempo em que mobiliza na prática interdisciplinar paradigmas evolucionistas cada vez mais obsoletos (epistêmicamente e ético-politicamente). Mas parece-nos importante dizer que esse movimento cognitivo se opera, explicando melhor, por intermédio de uma espécie de "reciclagem" das teorias evolucionistas, aproveitando-se delas residualmente e impondo um direcionamento regressivo as mesmas. Essa aparente contradição na epistemologia da história de Viana mais do que um erro em termos de teoria do conhecimento deve ser concebida como um indício das transformações observadas naquele contexto específico. Podemos arriscar uma 
explicação mais acertada: o que acontece é que se assume a pluralidade de evoluções, o que leva o nosso autor a destacar cada uma das linhas evolutivas (causas) a partir de uma teoria social particular (evolucionista ou não). Os evolucionistas conjugados informam uma consciência espectral da temporalidade, bem como uma concepção condicional da ação social. Ademais, as linhas evolutivas são complementadas pela regressão. Quer dizer, esse registro evidencia o fenômeno de coexistência das formas de síntese.

\section{Em busca da ressurreição: a história enquanto arte literária}

Para Viana, a indução conjectural orientada pela ciência propõe uma nova forma de fazer ver a experiência histórica: ela instaura um olhar sinóptico sobre esta considerando a pluralidade complexa de causas que governam uma situação ou um fato histórico-social. Ademais, esse procedimento proporciona uma perspectiva de história retrospectiva. É um esquema teórico-prático que leva em consideração “o contingente das realidades, que não puderam ser fixadas pelos textos escritos ou guardados pelos testemunhos orais" (VIANA, 1924, p. 442). Essa forma específica de entender e de operar a experiência da história possui dimensões de presentificação, ou mobilizando a famosa metáfora epistêmica do historiador francês Jules Michelet apropriada por nosso autor, de "ressureição", posto que torna presente um passado que se movimenta para além das orientações de sentido proporcionadas pela crítica dos documentos históricos, mas que se mostra condizente com uma projeção conceitual total articulada com "beleza" expositiva. Cabe dizer que essa maneira específica de lidar com a experiência temporal, ou tecido histórico-social das sociedades, faz do conhecimento histórico, em tese, uma "obra de arte". Em suas palavras: a "indução conjectural" cientificamente controlada "permite fazer da História realmente uma ressurreição, isto é, uma bela obra de arte que nem por ser uma bela obra de arte, deixa de ser uma verdadeira obra de ciência" (VIANA, 1924, p. 442). Nessa direção, indo além da documentação de arquivo e dos vestígios indiciários visíveis e orais, a nova crítica, amparada pelo artifício da “indução conjectural”, tem "conseguido desvendar o mistério de certos enigmas, que apenas com os elementos arquivais the seria impossível esclarecer" (VIANA, 1924, p. 442). A crítica atravessada pela "indução conjectural" movimenta-se regressivamente e fomenta a dimensão explicativa da história, capaz de evidenciar o invisível da história, só possível de ser operacionalizado pelas artes literárias.

Assim, após destacar as principais características próprias da fundamentação epistemológica da história, Oliveira Viana admite que ela não é tão somente um produto 
científico, mas, igualmente, uma "obra de arte". Essa identidade própria do produto intelectual do historiador torna ainda mais complexo o entendimento das sínteses modernistas. O estudioso de Saquarema admite que pelo fato da história também se localizar no terreno da "arte grande" parte dos seus comentadores e dos seus "obreiros" não a reconhecem como ciência. Isso é, para Viana, uma tremenda falha epistêmica. Argumenta o nosso autor: "De mim, confesso, senhores, que ainda não pude perceber bem esta incompatibilidade entre verdade e beleza" (VIANA, 1924, p. 444). A dimensão artística impressa nas obras de história é, para Oliveira Viana, uma reminiscência do métier advinda de um momento anterior ao da constituição da história disciplinada e, também, das ciências sociais. Sem os subsídios dos métodos de pesquisa e dos dados científicos a história, na antiguidade, apresenta-se enquanto uma obra artística. No entanto, deve-se considerar essa questão relacionada ao pecúlio artístico dos antigos junto à escrita da história da passagem para o século XX brasileiro como algo em disputa. A posição de Oliveira Viana não é, pois, absoluta. Bárbara Winther acredita, por exemplo, que os historiadores da antiguidade clássica "não são considerados exemplos a serem seguidos em todos os aspectos. Um desses aspectos diz respeito à aproximação com a literatura, a forma poética de escrita, considerada por alguns dos autores que analiso uma forma que não se adéqua à escrita da história" (SILVA, 2015, p. 21). Por outro lado, Vicente Detoni recupera as pouco conhecidas prescrições sobre a história e sobre a historiografia saídas da pena do anarquista José Oiticica, publicadas em 1910, onde se salienta que as exigências por imparcialidade e por objetividade são perpassadas por uma demanda própria do "domínio da arte da exposição" (DETONI, 2019, p. 46). Já Ivan Norberto assegura a existência da aceitação da dimensão artístico-literária por certa parte dos historiadores republicanos: a “qualidade literária da narrativa, portanto, não era então fator de desmerecimento para a elaboração do conhecimento histórico, sendo, para muitos, peça fundamental da sua realização" (SANTOS, 2009, p. 63).

Ou seja, para não poucos intelectuais a história se comporta como a grande ciência capaz de subsidiar as demais disciplinas em direção a um conhecimento total (contrafactual), bem naquilo que concebemos como episteme modernista. Ela faz a articulação dos saberes, como quer Oliveira Viana, por meio do componente artístico intrínseco à sua urdidura de intriga, sendo, pois, construtora de ekphrasis, que no vocabulário de Viana representa o processo de exposição literária ou "pictórica" do passado tal qual uma "ressurreição". Para o autor, "a História não é apenas uma grande 
ciência; é também e magnificamente, uma grande arte, - e essa condição de grande arte ainda torna mais complexo o labor da síntese histórica" (VIANA, 1924, p. 444).

É justamente por ser uma "obra de arte", transbordando a "obra de ciência", que certos interlocutores, entre eles Oliveira Viana, a consideram capaz de transcender o mimetismo historiográfico, fazendo do conhecimento histórico mais que a verdade considerada como adequação às formas. Ensaísta contemporâneos, que matizam o grau elevado de objetividade em suas pesquisas, concordam com essa proposição específica de Oliveira Viana, tais como Paulo Prado, com seu Retrato do Brasil (1928), e Gilberto Freyre, autor de Casa-grande e senzala (1933). Cabe frisar que a demanda moderna por tornar a história perspectivada faz dela uma "arte de narrar versões". A história é ciência por conta, também, do poder estético que a narrativa provoca. Viana diz não encontrar diferença, em seu discurso prescritivo, entre ciência e arte, na medida em que isso significa criar uma cisão, desnecessária, entre a verdade e a beleza. A arte literária presente na narrativa histórica, para o estudioso, ainda atende as prerrogativas de certa "teoria do gosto".

Segundo o nosso autor, nas páginas escritas por Xenofonte, por Tito Lívio, por Tucídides e por Tácito a história revela-se como uma verdadeira obra de arte - arte da narração, arte da criação e arte da ressureição, em sentido micheletiano. Contemporaneamente, mesmo com a propagação dos métodos objetivos, a face artística da história ainda ressoa, "colorida" e "eloquente", nas páginas de Taine, de Carlyle, de Vandal e de Michelet, responsáveis por transmitir as tradições artísticas em historiografia. Por isso Thomas Seccombe chega a argumentar o seguinte: "nenhum historiador podia considerar-se verdadeiramente grande, se não possuísse a capacidade verbal e o talento descritivo de dois ou três grandes romancistas" (VIANA, 1924, p. 445).

Oliveira Viana acredita que a condição de ser, também, “obra de arte” parece configurar-se no traço mais original da ciência da história; o fator que a torna distintiva no conjunto das demais ciências, mesmo entre aquelas que servem de auxiliares. Assim, as ciências sociais que dialogam com a história no processo de investigação não se valem da explanação artística, deixando essa particularidade para os artífices de Clio. De acordo com as suas palavras

São estas artes que emprestam a obra do historiador esse interesse, essa sedução, que suscita a curiosidade de todos os espíritos pelas épocas passadas. Sem o encanto e poesia, que elas derramam, o passado interessaria apenas a um círculo limitado de estudiosos - e a História seria, como a Geografia, a Etnografia e a Antropologia, um 
domínio limitado, um campo circunscrito e privativo, onde somente penetraria um certo número de curiosidades e especialidades, isto é, os próprios historiadores (VIANA, 1924, p. 445).

Quer dizer: o conhecimento histórico está para além da sua dimensão especializada, ou seja, internalista. Ele deve abranger, também, a curiosidade criativa e fomentar a sedução pelo passado entre os mais distintos públicos, não apenas entre os pares historiadores. Esse registro é uma demanda (romântica?) do gosto. O que se verifica é a história abrindo um campo comum procurado por todos os "espíritos", das mais variadas estirpes, tendências e especialidades. A história, para tanto, deve conter beleza expositiva, podendo movimentar suplementos estéticos. É exatamente essa característica que a torna interessante. Assim, tudo concorre para a elevação do seu fascínio e da sua sedução. "Ora, esta curiosidade tão universal pelas obras de História tem a sua razão de ser neste caráter inevitavelmente artístico de toda ressureição histórica" (VIANA, 1924, p. 445).

A metáfora micheletiana da "ressureição" tem, em Oliveira Viana, a função de relembrar e de celebrar os mortos fazendo-lhes justiça. O métier do historiador aproxima-se, nesse sentido, do sacerdócio (SCHREINER, 2005, p. 162). Ou seja, a partir do momento em que ele ritualiza o plano das ações e dos sacrifícios realizados por homens e por mulheres do passado é impresso um movimento de estetização da memória dos mortos, isto é, o componente artístico da ressureição à moda micheletiana. De qualquer forma, veremos que a metáfora da "ressureição" não é, para Viana, totalmente satisfatória no plano da reconstrução da realidade histórica. Por qual razão?

\section{Patriotismo, ou a história da "terra dos pais"}

Viana deixa claro que o saber histórico, a sua evocação, não possui apenas o valor de uma satisfação que visa o lazer e a especulação, dado que manifesta um alto grau de "pragmatismo". As sínteses históricas devem abranger preocupações públicas. Isso é uma herança das sínteses historicistas, como se pode ver, por exemplo, nas prescrições de Leopold von Ranke. Essa disposição também pode ser assistida através da proposta de história filosófica de Von Martius, bastante influente no século XIX. Percebe-se que história pragmática subscreve o balanço das experiências humanas proposto pelas sínteses a partir de preocupações públicas. A história, científica em sua fundamentação, tem como horizonte a consecução de uma finalidade pragmática, quer dizer, ela necessita encontrar o sentido maior (tendências) dos fatos, o que não significa, necessariamente, falta de neutralidade. O pragmatismo em história possui um forte apelo social. 
Para além da suspensão de certo aspecto supostamente abstracionista, a história (pátria) tem como intuito a correção das percepções distorcidas sobre a identidade da nação. O Brasil é percebido por Oliveira Viana como um “jovem país” que se apresenta em marcha continuada, diferentemente de alguns povos europeus, por exemplo. Ao invés de uma lição de resignação busca-se um aprendizado circunstanciado pelo entusiasmo e pela "fé”, pela valorização patriótica e por meio de uma consciência mais iluminada acerca do futuro. A história da pátria é uma fonte de agenciamento social que fortalece os modos da nação se reencontrar consigo mesma.

Não é por outro motivo que Tristão de Alencar Araripe, em suas Indicações sobre a história nacional (1894), adverte que a pátria "não é um nome vão; antes é objeto do amor de seus filhos". Por meio do horizonte patriótico os povos "cultuam" os mais nobres sentimentos de veneração para com os seus antepassados, dado que ninguém deixa de interessar-se pelo seu "torrão natal” (ARARIPE, 1894, p. 259). O Conselheiro Araripe afirma, nesse sentido, que é por meio do sentimento pátrio que os povos incorporam o movimento social e tomam parte na vida cívica: "olhamos em torno de nós, vendo o solo, em que pisamos, e em que nos agitamos com os nossos concidadãos, logo um dos primeiros sentimentos despertados em nós é o de queremos saber o que foi essa região, onde nos achamos, e porque modo chegou a presente situação" (ARARIPE, 1894, p. 259). Escrever a história pátria é um desafio para aqueles que pretendem colocar em evidência os caracteres formativos de um dado agregado coletivo anteriores até mesmo ao entendimento da nação. Assim, cabe destacar que o sentimento patriótico se apresenta ôntico, lógico e cronologicamente anterior ao de nação. Falar em pátria significa atribuir sentido a um substrato identitário com dimensões propriamente antropológicas, posto que colocado em modo de anterioridade. A identidade do passado pátrio é adjetivada positivamente por Oliveira Viana.

Uma primeira utilidade pragmática investida no estudo da história pode ser aquela que admite a "veneração do passado" como forma de prever o futuro. É uma maneira particular de enaltecer a identidade patriótica da história e uma forma de aprendizado. Essas duas instâncias, patriotismo e pragmatismo, coadunam-se sem justaposição. De forma tal que se dilata, se robustece e se intensifica, pela história, o sentimento de amor pátrio. É a consciência, em cada brasileiro e em cada brasileira, do aumento do sentimento de respeito pela ancestralidade nacional como uma espécie de patrimônio que deve ser transmitido. Assim, como forma de articular a história em uma "narrativa épica de heroísmo" faz-se necessário que a "ressureição" se transforme em 
"reencarnação". Ao dotar de sentido a experiência o historiador se apresenta como o diretor que dramatiza. Ele revive os cenários, simbólicos ou espaciais, em que a heroicidade de homens e de mulheres prevalece, e os conecta ativamente no presente. Por isso argumenta-se que não há nenhum historiador que seja um mau patriota. São dois polos intercruzados. O desafio da história é tornar o passado da nação atravessado pelo patriotismo, investigando os momentos em que esse sentimento se materializa em ações efetivas que podem (e devem) movimentar toda uma disposição histórico-social presente. "Este é um dos mais belos aspectos da utilidade pragmática do estudo do passado: é uma das mais nobres, senão a mais nobre escola de patriotismo e de dignidade cívica (VIANA, 1924, p. 450). Falar em termos de "reencarnação" do passado, indo além da "ressureição", significa ativar a dimensão formativa do passado, incidindo nas ações de homens e de mulheres de forma moderna de maneira tangível (via representações sociais). No caso da agência incutida na reapresentação do passado patriótico há uma percepção político-intelectual positivada.

Ao propor a escrita da história da pátria percebemos que Oliveira Viana admite a possibilidade da narração, por meio de um processo de identificação, do destino de comunidades étnico-culturais, como o Brasil. "É que, se estas implicam o compartilhamento de características comuns (os mesmos mitos de origem, a mesma língua, um mesmo território, a mesma memória coletiva), é indiscutível que a sua pedra de toque se situa na ancestralidade" (CATROGA, 2011, p. 14). Lembrando que Viana ainda mobiliza a noção de "raça". A pátria é o "húmus sagrado" em que se reproduz uma espécie de filiação a uma determinada herança: aquela que assinala o destino manifesto da memória coletiva direcionada por meio de uma transmissibilidade geradora da ordem social (CATROGA, 2011). Ela é a condição para a percepção do nacional. É interessante destacar que os extratos de tempos patrióticos não são perpassados pelo signo do atavismo. A pátria é a

\footnotetext{
terra do nossos país, logo o mundo em que viveram os nossos antepassados, e esse mundo não é apenas o solo na sua materialidade, é também o solo na sua espiritualidade, centro larario da grei, com as tradições que eles criaram, com a civilização que fundaram, com as dores que sofreram, com as alegrias que tiveram, com as glórias e triunfos que alcançaram (VIANA, 1924, p. 450).
}

A consequência dessa disposição argumentativa mostra-se bastante clara: através da perspectiva patriótica que as comunidades ou os grupos sociais, e estamos falando em termos de Estado e de nação chegando ao ponto extremo do cidadão, podem narrar de forma estável a sua própria história, reconhecendo-se identitariamente. O patriotismo é uma forma de aprendizado, que ser quer moderno, sobre a história. Dessa maneira, em 
busca de certa ancestralidade fundacional as comunidades compartilham características comuns: as mesmas ficções de fundação, o mesmo idioma, o mesmo território e a mesma memória coletiva e cultural. No caso de Viana deve-se perceber, também, o fator hereditariedade racial. Essa "terra dos pais", e as suas respectivas fícções fundacionais, torna-se metaforicamente a "origem das origens", uma base segura, e de certa maneira sacralizada, que se constrói, se filia e se identifica. Pode-se dizer, em última medida, que a pátria é o "espírito" da nação. A relação da nação com a pátria é a forma segura desta se precaver (e se distanciar) diante dos "males" do passado que atingem o presente do país. O sentimento patriótico, na ótica de Oliveira Viana, orgulha-se do passado mesmo ante certos momentos de obscuridade.

Para Yi-Fu Tuan, uma pátria impõe referenciais que fazem os seres humanos se identificarem, podendo ser de grande visibilidade e relevância pública, tais como monumentos, templos, campos de batalha sagrados ou até mesmo cemitérios. Eles existem em razão do sentimento de identidade coletiva, incentivam a consciência e a lealdade para com um lugar (geográfico e/ou simbólico). Mas essa afeição à pátria pode se concretizar através de gestos pequenos: ter familiaridade com um lugar natalício, a certeza da alimentação e da segurança, as recordações de sons e de odores, a rememoração de atividades e prazeres mínimos acumulados ao longo do tempo. Viana tem como ambição apreender essas experiências. A pátria é como a "energia vital" da nação. Yi-Fu Tuan argumenta, ainda, que a pátria é uma concepção coletiva onde os homens e as mulheres partilham referenciais de forma intersubjetiva. A afeição patriótica é, nesse sentido, um fenômeno de escala mundial. Ela não se vinculada à nenhuma cultura ou sociedade em especial, variando de intensidade entre os diferentes períodos históricos (TUAN, 2013). A história pátria garante a sobrevivência e a difusão desse patrimônio de referenciais socialmente construído.

Assim, o autor das Populações meridionais (1920) não deixa de explicar que essa admiração pelo passado não significa, necessariamente, um simples retorno ao mesmo ou a falta de apreço pelo presente, menos ainda uma indiferença pelo futuro. É, de outra forma, a percepção da "reencarnação" dos valores vitais do passado necessários à identidade civilizacional da sociedade brasileira em movimento. É o reconhecimento do âmbito positivo do passado como instância vital para desenvolvimento do devir histórico nacional até a sua condição hodierna por intermédio de uma performance agenciadora. Não é apenas a celebração do passado, como na "ressureição", mas é a consciência do passado atuando no presente de modo a formar o processo histórico. É, mesmo, uma "reencarnação". A história é percebida como uma "escola de educação 
cívica", sendo fator determinante no desenvolvimento do sentimento patriótico e mesmo de "consciência coletiva" nacional. Assim, a "moral da história", investida pragmaticamente, vai ao encontro tanto das melhores emulações cívicas quanto dos "nossos grandes problemas nacionais".

Destacamos que a ideia a qual a história brasileira atende as prerrogativas do patriotismo não se apresenta necessariamente como uma inovação em termos historiográficos, mesmo que seja possível ponderar que os seus usos na República possuem uma nova conotação semântica e uma nova utilidade prática. Karl von Martius destaca, por exemplo, em sua premiada Dissertação (1845), texto fundacional da moderna historiografia brasileira, as virtudes de uma escrita da história patriótica. Para o naturalista, atento aos preceitos de Cícero, a história é uma mestra, porém ela ensina modernamente via experiência o presente, e mesmo o futuro, de modo transformador: "Ela pode difundir entre os contemporâneos sentimentos e pensamentos do mais nobre patriotismo". A escrita da história atinge o sentimento do "amor pátrio", o que significa não a conceber através de um olhar exterior. Assim, virtudes cívicas emergem em forma de ação social: coragem, constância, indústria, fidelidade e prudência (MARTIUS, 2010). Tristão de Alencar Araripe atualiza Martius: "o historiador [é o] benfeitor da pátria, se souber no manejo da pena escolher assuntos a figurar os grandes moldes, em que deve fundir-se o patriotismo brasileiro" (ARARIPE, 1894, p. 264).

O que a observação atenta da intelectualidade Ocidental assinala, argumenta Viana, sobre os povos que se tornam devotos do patriotismo, dilatando o sentimento nacional a partir do orgulho da sua grandeza presente e da consciência do seu futuro benfazejo, não relaciona-se de forma alguma com o desinteresse pelo passado ou com a abdicação das tradições. Se quer preservar, no limite, traços importantes inscritos na continuidade histórica. Assim, todo movimento de exortação ao patriotismo é um movimento de valorização (eletiva) do passado. O horizonte de expectativas passa a ser dependente de um espaço de experiência positivo. Quer dizer, o patriotismo é a fórmula que parece adequada para a superação (e defesa) das transformações negativas impostas pela modernidade, dotando de continuidade (eletiva) a consciência histórica nacional, de modo a imprimir uma consistente consciência formativa que otimiza o processo histórico.

\section{Determinantes da personalidade coletiva}

Oliveira Viana afirma que os grupos sociais são como os indivíduos em razão de desenvolverem padrões e linhas formativas mentais relativamente estáveis em meio à 
mobilidade do devir, constituindo o que se pode denominar, apropriando-se metaforicamente de prescrições elaboradas pelo biólogo evolucionista August Weismann, como "determinantes da personalidade coletiva". Ou seja, mesmo destacada a pluralidade de causas que enredam um dado conjunto de fenômenos históricos, e a sua complexidade subjacente, Viana concorda, sem que isso lhe pareça uma contradição, que haja determinação em história. No caso, visível em certos comportamentos psicossociais. Essas “determinantes" aparecem como elementos estruturantes do povo nas condições mais profundas do seu viver, nas particularidades da sua mentalidade. Em todas essas situações verifica-se um quid immutabile. Ou seja: no âmbito do desenvolvimento social existe uma série de permanências, de regularidades e de continuidades psíquicas em meio a uma concepção pluricausal de história. É em razão do seu desconhecimento que as ações públicas não se encaixam perfeitamente junto à ordem social. Assim, “o conhecimento dessas 'determinantes' nacionais é, pois, essencial à ação de todos que exercem uma função dirigente na sociedade, principalmente os que tem cargo da direção política (VIANA, 1924, p. 451). É possível racionalizar e prever as performances e as tendências dessas determinantes. Assim, aprender com a história significa empreender uma análise conjuntural aumentando a previsibilidade do futuro. A aceitação da existência de determinantes em história significa a anuência de uma disposição temporal na qual o passado se impõe sobre o presente. Cabe a pragmática da história intervir nos seus impactos negativos junto à mentalidade coletiva da nação, podendo positiva-lo patrioticamente visando a transformação. Por outro lado, em termos ético-políticos, esse é o argumento ideológico para a execução do "autoritarismo instrumental" (SANTOS, 1978), postura política desejada por Viana.

Mas o "passado reencarnado" pode mostrar-se atávico. A pragmática da história serve como uma forma de prever as tendências negativas do passado que se desdobram atuantes no presente. $\mathrm{O}$ que se deve ter em mente é que há determinantes negativas poderosas, chegando a incidir na personalidade coletiva e nos modos de agir dos sujeitos, de modo a condicionar a consciência social de forma inibidora. Viana não é um “determinista clássico", registro em que se percebe que todos os fenômenos da natureza, no caso histórico-sociais, estão ligados entre si por rígidas relações de causalidade e leis científicas universais que excluem o acaso e a indeterminação, como no caso das sínteses evolucionistas. Mesmo sendo leitor de autores como Hippolyte Taine a sua postura regressiva lhe oportuniza modificar o passado. O que se observa é um processo de hibridação de paradigmas de cariz sociológico evolucionista e pós-evolucionista, 
determinista e pós-determinista, podendo ser escolhido, ainda, um ou outro dependendo da especificidade histórico-social em questão. Constata-se que a concepção de tempo de Viana sinaliza que o passado se performa no modo de agência no presente de um modo que pode ser negativo. Porém, como ele desenvolve o "método regressivo" acredita-se na possibilidade da transformação do passado e na alteração dos efeitos negativos da sua agência no presente. Esse aparelhamento epistêmico lhe propicia interferir na "reencarnação do passado" verificada no devir histórico. Essa é a forma que Viana encontra para interditar a herança indesejada, em muitos casos mortificante, do passado agenciada pelas "determinantes da personalidade coletiva" negativas em forma de representações psicossociais.

O que se vê no caso da interpretação de Viana é, em primeiro lugar, que os sujeitos se mostram "determinados" pela sociedade por variados ângulos, condicionando condutas e comportamentos específicos. O seu diagnóstico apresenta um sujeito perpassado por diferentes condicionantes. O autor tende a eleger, em sua obra, aquelas que possuem algum grau de atavismo junto a ação social. Mas é necessário perceber este raciocínio: pluricausalidade implica pluriefeitos no presente. Assim, Oliveira Viana coloca luz alta sobre efeitos, como forma de exercitar a sua pragmática da história, negativos do passado, como pode ser percebido nas representações psicossociais que assinalam "inconsciência coletiva" no plano da ação política democrática.

Porém, o conhecimento da história, da experiência da história, através de um aparelhamento epistemológico apropriado, podendo ser aquilo que Oliveira Viana chama de pragmática da história, é uma forma de dirigir as "determinantes" negativas da sociedade brasileira e atuar em suas linhas de força junto às representações sociais. A reconstrução do passado em Viana não deixa de ser uma utopia política, visto que o acompanhamento crítico de certas "determinantes" na atualidade, especialmente psíquicas, aparece como uma forma de intervir no próprio passado, o interditando, então, no processo de agenciamento negativo do presente. $\mathrm{O}$ "método regressivo" serve, assim, para o conhecimento da história como devir. Mas esse registro de saber desenvolve um efeito que custa caro: somente o Estado autoritário é capaz, em tese, de realizar esse movimento político-intelectual.

É a partir dessa constatação que Oliveira Viana apresenta, ao analisar a política brasileira, a noção de "idealismo utópico", que significa a falta, pois, de tato conjectural por parte dos nossos homens de Estado em se tratando das "verdades fundamentais" do Brasil. Em razão dessa diagnose, a do "Brasil legal" e a do "Brasil real", observa-se a 
inoperância da constituição e das reformas políticas. Tudo isso por conta desses agentes políticos desconhecerem as tendências essenciais da formação do país (as determinantes negativas da mentalidade social), o que impossibilita, via de regra, toda e qualquer forma de planejamento político e social. É no plano da ação social que se localiza o condicionamento das condutas humanas, o que não significa a determinação fixa e imutável dos sujeitos históricos. Como disse o próprio Oliveira Viana: há um "quid immutabile”, ou seja, um "quê" de imutabilidade. O estudioso carioca movimenta um vocabulário que pode levar-nos a interpretá-lo como um determinista clássico, quando a sua consciência é condicionalista.

A aceitação da existência das "determinantes da personalidade coletiva" negativas condiciona o livre arbítrio. Vê-se que os males de origem da nação, em Viana, se situam no âmbito de condicionantes negativas (que implica várias causas), mais especificamente no registro da "inconsciência democrática". Esse diagnóstico chega, então, à dimensão psíquica, pois através do plano visível da interação social "subsiste e palpita todo um vasto mundo de forças organizadas, de tendências, de instintos, de impulsões misteriosas, que forma o sistema das correntes subterrâneas que circulam no subconsciente das nacionalidades" (VIANA, 1924, p. 451). A ambição de Viana é, pela reconstrução da realidade histórica, suspender as linhas negativas de determinação da mentalidade coletiva responsáveis pela propagação de representações psicossociais atávicas

Assim sendo, o passado exerce sobre a contemporaneidade a sua força sutil e poderosa. "Vivemos envolvidos de todos os lados pela atmosfera impalpável e imponderável das suas sugestões, e inconscientes quase sempre da sua influência invisível e profunda" (VIANA, 1924, p. 452). Quer dizer: Oliveira Viana quer despertar os agentes sociais para o esclarecimento das condicionantes que circunscrevem as suas vidas, oportunizando o desvelamento de conjuntos de causas (o passado) que atingem aspectos específicos das ações sociais (e comportamentais) por eles engendradas. Parece evidente, pois, que o estudo da história, o conhecimento do passado, a abordagem da experiência da história, passa a ter, em Viana, grande valor e termos de pragmática.

É o que se pode ver em suas críticas à inadequação da constituição federativa no Brasil. Para Viana há três incoerências entre a lei e a realidade visíveis na implementação desse modelo político. Primeiro: ao estabelecer o federalismo, atribuindo autonomia aos Estados, essa forma de liberalismo político inviabiliza "a elaboração e implementação de uma política orgânica voltada para os interesses nacionais, permitindo, ainda, que a política do Executivo central permanecesse 
submissa aos interesses das mais poderosas oligarquias regionais" (SILVA, 2008, p. 8). Segundo: as funções legislativas, ao interferirem demasiadamente no plano executivo, impedem uma administração pública considerada moderna e centralizada, isto é, esse estado de coisas abona a permanência das oligarquias regionais no poder. Terceiro: “o modelo democrático liberal permitiria que a irracionalidade e o apoliticismo prevalecentes no comportamento popular pudessem ser transferidos para as esferas decisórias estatais" (SILVA, 2008, p. 9). Somente o conhecimento regressivo dessas tendências da mentalidade coletiva torna possível um verdadeiro entendimento das exigências da política e da sociedade brasileiras. Entre essas "determinantes" talvez a mais impactante, e negativa, seja o "insolidarismo social", uma típica representação social brasileira.

Assim sendo, é através do esclarecimento do passado, da sua abordagem crítica, da sua compreensão em perspectiva regressiva, que se faz possível deixar em relevo as performances das "determinantes da personalidade nacional". Registros com persistência social, cujo conhecimento parece ser incontornável para o êxito de qualquer movimento renovador. Por isso, o estudo da história tem valor pragmático: ele percorre a experiência da história e acompanha as suas principais tendências com interesse público (mas não partidário). Para Oliveira Viana, o conhecimento histórico possui uma missão estratégica: serve de guia condutor para as ações das classes dirigentes. É um movimento, então, de sobrevivência das sínteses historicistas. Nesse sentido, Angela de Castro Gomes argumenta que o Estado idealizado por Oliveira Viana, uma das suas grandes preocupações em termos de estudos por cerca de quatro décadas, necessita, em suma, "aceitar a existência de práticas e mentalidades sociais" que funcionam enquanto "balizas que 'ajustam/orientam"” (GOMES, 2009, p. 155), posto que estabelecem tendências, possíveis intervenções junto à ordem psicossocial historicamente constituída.

\section{Referências}

ANHEZINI, Karina. Um metódico à brasileira: a história da historiografia de Afonso de Taunay (1911-1939). Tese (Doutorado em História) - Programa de Pós-graduação em História, Universidade Estadual Paulista, 2006.

ARARIPE, Tristão de Alencar. Indicações sobre a história nacional. RIHGB, tomo 57, parte II, 1894.

BECHELLI, Ricardo Sequeira. Metamorfoses na interpretação do Brasil. Tensões no paradigma racial (Sílvio Romero, Nina Rodrigues, Euclides da Cunha e Oliveira Vianna). Tese (Doutorado em História) - Programa de Pós-graduação em História Social: Universidade de São Paulo, 2009. 
BLOCH, Marc. Apologia da história, ou o ofício do historiador. Rio de Janeiro: Jorge Zahar, 2001.

BOTELHO, Tarcísio Rodrigues. A Família na Obra de Le Play. DADOS - Revista de ciências sociais, Rio de Janeiro, vol. 45, n. 3, 2002.

BRESCIANI, Maria Stella Martins. O charme da ciência e a sedução da objetividade. Oliveira Vianna entre intérpretes do Brasil. São Paulo: Editora UNESP, 2007.

CATROGA, Fernando. Pátria e nação. Paraná: Centro de Documentação e Pesquisa de História dos Domínios Portugueses da Universidade Federal do Paraná, 2011/2012, p. 15 .

CERTEAU, Michel de. A escrita da história. Rio de Janeiro: Forense Universitária, 2006.

DETONI, Piero di Cristo Carvalho. A síntese como desafio historiográfico na Primeira República. Pequenos estudos de caso. Dissertação (Mestrado em História) - Programa de Pós-graduação em História, Universidade Federal de Ouro Preto, 2013.

DETONI, Vicente da Silveira. A moderna historia magistra vitae de José Oiticica: regimes historiográficos e ordem do tempo no Brasil (c. 1870 - 1940). Dissertação (Mestrado em História) - Programa de Pós-graduação em História, Universidade Federal do Rio Grande do Sul, 2019.

GOMES, Angela de Castro. A república, a história e o IHGB. Belo Horizonte/MG: Argumentum, 2009.

GOMES, Angela de Castro. História e historiadores. Rio de Janeiro: FGV, 1996.

GOMES, Angela de Castro. Oliveira Vianna: um statemaker na Alameda São Boaventura. In: BOTELHO, André; SCHWARCS, Lilia Moritz. Um enigma chamado Brasil. São Paulo: Companhia da Letras, 2009.

HRUBY, Hugo. Obreiros diligentes e zelosos auxiliando no preparo da grande obra: a história do Brasil no Instituto Histórico e Geográfico Brasileiro (1889-1912). Dissertação (Mestrado em História) - Programa de Pós-graduação em História, Pontifícia Universidades Católica do Rio Grande do Sul, 2007.

IGGERS, Georg G. Historiography in the twentieth century: from scientific objectivity to the postmodern challenge. Hanover and London: Wesleyan University Press, 1997.

IUMATTI, Paulo Teixeira; VELLOZO, Julio César De Oliveira. "Conhecimento, política e instituições no Brasil (1889 - 1934). Reflexos - Revue pluridiscipinaire du monde Lusophone, n. 2, 2013.

MARTIUS, Karl von. "Como se deve escreve a história do Brasil”. In: GUIMARÃES, Manoel Luiz Salgado. Livro de fontes de historiografia brasileira. Rio de Janeiro: EDUERJ, 2010.

NOVIK, Peter. That noble dream: the objectivity question and the American historical profession. Cambridge University, 2008.

OLIVEIRA, Maria da Glória de. Crítica, método e escrita da história em João Capistrano de Abreu. Rio de Janeiro: Editora FGV, 2013.

OLIVEIRA, Rodrigo Perez. Por que vendem tanto? O consumo de historiografia comercial no Brasil em tempos de crise (2013-2019). Revista Transversos, Rio de Janeiro, n. 18, 2020.

PEREIRA, Mateus H. F.; SANTOS, Pedro Afonso C. Odisseias do conceito moderno de história: Necrológio de Francisco Adolfo de Varnhagen, de Capistrano de Abreu, e O 
pensamento histórico no Brasil nos últimos cinquenta anos, de Sérgio Buarque de Holanda, revisitados. Revista do IEB, São Paulo n. 50, 2010.

PEREIRA, Mateus H. F.; SANTOS, Pedro Afonso C.; NICODEMO, Thiago Lima. Uma introdução à história da historiografia brasileira (1870 - 1970). Rio de Janeiro: Editora da FGV, 2018.

REIS, José Carlos. "História e verdade". Síntese - Revista de Filosofia, Belo Horizonte vol. 27 , n. 89, 2000.

REIS, José Carlos. Os annales: a renovação teórico-metodológica e "utópica" da história pela reconstrução do tempo histórico. In: Encontro nacional do HISTEDBR, s/d. Anais do IV Encontro nacional do HISTEDB, s/d,

RODRÍGUEZ, Ricardo Vélez. Francisco José de Oliveira Vianna. O homem e a sua obra. Proyecto Ensaio Hispânico, 2003.

SANTOS, Ivan Norberto. A historiografia amadora de Rocha Pombo: embates e tensões na produção historiográfica brasileira da Primeira República. Dissertação (Mestrado em História Social) - Programa de Pós-graduação em História Social, Universidade Federal do Rio de Janeiro, 2009.

SANTOS, Wanderley G. Ordem burguesa e liberalismo político. São Paulo: Duas Cidades, 1978.

SCHREINER, Michelle. Jules Michelet e a história que ressuscita e dá vida aos homens. Uma leitura da emergência do "povo" no cenário historiográfico francês da primeira metade do século XIX. Tese (Doutorado em História) - Programa de Pósgraduação em História: Universidade de Campinas, 2005.

SCHWARCZ, Lilia K. Moritz. Os guardiões da nossa história oficial. Série História das ciências sociais, IDESP, 1989

SILVA, Bárbara Winther da. A escrita da história no IHGB no final do Império e Primeira República. Dissertação (Mestrado em História) - Programa de Pós-graduação em História: Universidade Federal Rural do Rio de Janeiro, 2015.

SILVA, Ricardo. Liberalismo e democracia na Sociologia Política de Oliveira Vianna. Sociologias, n. 2, vol. 20, 2008.

TUAN, Yi-Fu. Afeição pela Pátria. In: Espaço e lugar: a perspectiva da experiência. Londrina: EDUEL, 2013.

TURIN, Rodrigo. A disciplina histórica e a historicidade das formas disciplinares. Alguns apontamentos. Mimeo, 2016.

VIANA, Francisco José de Oliveira. Discurso de posse. RIHGB, tomo 96, parte II, 1924.

VIANNA, Francisco José de Oliveira. Populações meridionais do Brazil (história organização - psicologia). Primeiro volume. Populações rurais do centro-sul (paulistas - fluminenses - mineiros). São Paulo: Monteiro Lobato \& Cia. Editores, 1920.

WEHLING, Arno. A invenção da história: estudos sobre historicismo. Rio de Janeiro: EDUFF, 2001. 